\title{
Honoré De Balzac, Eugénie Grandet
}

\section{Marco Stupazzoni}

\section{(2) OpenEdition}

\section{Journals}

\section{Edizione digitale}

URL: http://journals.openedition.org/studifrancesi/8299

DOI: $10.4000 /$ studifrancesi.8299

ISSN: 2421-5856

\section{Editore}

Rosenberg \& Sellier

\section{Edizione cartacea}

Data di pubblicazione: 1 mai 2009

Paginazione: 192

ISSN: 0039-2944

\section{Notizia bibliografica digitale}

Marco Stupazzoni, «Honoré De Balzac, Eugénie Grandet», Studi Francesi [Online], 157 (LIII | I) | 2009,

online dal 30 novembre 2015, consultato il 07 janvier 2021. URL: http://journals.openedition.org/ studifrancesi/8299 ; DOI: https://doi.org/10.4000/studifrancesi.8299

\section{Questo documento è stato generato automaticamente il 7 janvier 2021.}

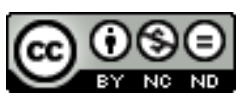

Studi Francesi è distribuita con Licenza Creative Commons Attribuzione - Non commerciale - Non opere derivate 4.0 Internazionale. 


\title{
Honoré De Balzac, Eugénie Grandet
}

\author{
Marco Stupazzoni
}

\section{NOTIZIA}

HONORÉ DE BALZAC, Eugénie Grandet, introduzione di Lanfranco BINNI, traduzione di Giorgio BRUNACCI, Milano, Garzanti, «I grandi libri», 2007, pp. LXI-175.

1 Segnaliamo la ristampa di questa traduzione italiana del romanzo balzachiano, la cui prima edizione, nella nuova versione di G. Brunacci, risale al 1984. L'ampio saggio introduttivo di L. Binni fornisce al lettore validi e puntuali riferimenti sulla formazione letteraria dello scrittore francese oltre che sulla genesi e lo sviluppo della sua opera. Meritevole di aggiornamenti almeno per gli ultimi dieci anni è al contrario la guida bibliografica presente alle pp. LVI-LXI del volume. 